\title{
BRPKM
}

Buletin Riset Psikologi dan Kesehatan Mental

http://e-journal.unair.ac.id/index.php/BRPKM

e-ISSN: 2776-1851

ARTIKEL PENELITIAN

\section{Pengaruh Psychological Well-Being terhadap Stres Akademik Siswa SMA di Masa Covid-19}

\author{
Zakiya Ainun Oktaviani \& Veronika Suprapti* \\ Fakultas Psikologi Universitas Airlangga
}

\begin{abstract}
ABSTRAK
Penelitian ini bertujuan untuk mengetahui pengaruh psychological well-being (PWB) terhadap stres akademik siswa SMA di masa Covid-19. Variabel PWB mengacu pada teori Ryff, sedangkan variabel stres akademik mengacu pada teori Olejnik \& Holschuh. Responden yang terlibat dalam penelitian ini adalah 147 siswa SMA yang sedang mengikuti pembelajaran jarak jauh. Teknik sampling menggunakan non probability sampling dengan metode purposive sampling. Pengumpulan data dengan skala BSPWB-A yang disusun oleh Viejo dkk. dan skala ESSA yang disusun oleh Sun, dkk. Teknik analisis data yang digunakan adalah uji regresi linier sederhana dengan bantuan program SPSS 22.0 for windows. Hasil analisis menunjukkan nilai $\mathrm{t}$ sebesar 23,606 > t tabel $(1,976)$, berarti $\mathrm{H}_{\mathrm{a}}$ diterima. Kemudian nilai koefisien regresi $\left(\mathrm{R}^{2}\right)$ sebesar 0,42 berarti variabel PWB memberikan kontribusi sebesar 42\% kepada stres akademik. Didapatkan pula persamaan regresi yaitu $Y=79,637-0,453$, disimpulkan bahwa PWB dan stres akademik berpengaruh negatif.
\end{abstract}

Kata kunci: pembelajaran jarak jauh, psychological well-being, siswa SMA, stres akademik

\section{ABSTRACT}

This study aims to determine the effect of psychological well-being (PWB) on high school students' academic stress during the Covid-19 period. The PWB refers to Ryff's theory, while the academic stress refers to the theory of Olejnik \& Holschuh. Respondents consisted of 147 high school students who were taking distance learning. The sampling technique used non-probability sampling with purposive sampling. Data collection with BSPWB-A scale compiled by Viejo, et al. and ESSA scale compiled by Sun, et al. The data analysis technique used is a simple linear regression test with SPSS 22.0 for windows. The results of the analysis show the t value of $23.606>t$ table (1.976), meaning $H_{a}$ is accepted. Then the value of $\mathrm{R}^{2}$ is 0.42 , means that PWB contributes $42 \%$ to academic stress. It was also found $\mathrm{Y}=79.637$ 0.453 , it's concluded that PWB and academic stress have a negative effect.

Keywords: academic stress, distance learning, high school student, psychological well-being

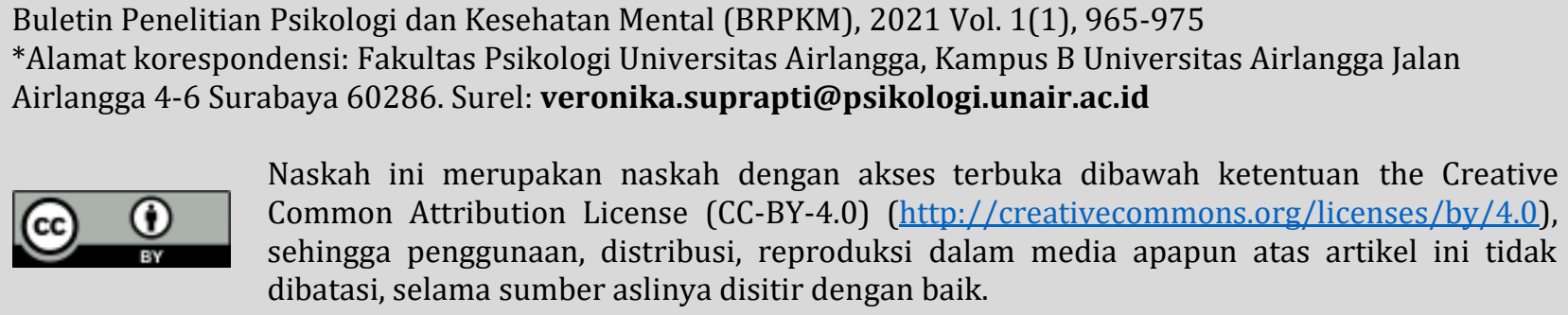

Naskah ini merupakan naskah dengan akses terbuka dibawah ketentuan the Creative Common Attribution License (CC-BY-4.0) (http://creativecommons.org/licenses/by/4.0), sehingga penggunaan, distribusi, reproduksi dalam media apapun atas artikel ini tidak dibatasi, selama sumber aslinya disitir dengan baik. 


\section{PEN D A H U L U A N}

Di awal tahun 2020, hampir di seluruh dunia diserang sebuah virus menular yang membahayakan. Virus ini ditemukan pertama kali di Wuhan, China. Virus yang disebut dengan Novel Coronavirus ini menyebar dengan cepat di seluruh China. Bahkan di akhir Januari, beberapa negara di luar China mulai menemukan kasus kematian akibat virus ini. Akhirnya Badan Kesehatan Dunia (World Health Organization) menetapkan Novel Coronavirus sebagai Public Health Emergency of International Concern (PHEIC) dengan sebutan Coronavirus Desease (COVID-19) (CDC, 2020).

Indonesia pun menggencarkan berbagai strategi pencegahan yaitu social distancing dengan penutupan sekolah maupun perguruan tinggi. Tidak hanya di Indonesia, penutupan sekolah maupun perguruan tinggi juga dilakukan hampir di seluruh dunia. Hal ini disebabkan karena kegiatan ajar-mengajar di ruang tertutup rentan diserang virus ini. Penutupan sekolah ini tidak dapat dipungkiri menimbulkan beberapa dampak negatif bagi pihak yang menjalankan. Utamanya di Indonesia, sekolah dari rumah adalah hal yang baru dan cukup rumit, karena tidak semua keluarga mampu mengajari anaknya sendiri apalagi dengan adanya keterbatasan akses internet. Oleh karena itu, tidak sedikit siswa yang merasa tertekan akibat sekolah daring.

Terlebih pada masa SMA, selama pandemi banyak pembatalan acara-acara membuat mereka kehilangan momen-momen besar yang telah mereka tunggu, seperti pembatalan Ujian Nasional (UN), Masa Pengenalan Lingkungan Sekolah (MPLS), tidak ada acara-acara sekolah seperti class meeting, pentas seni, dan lain sebagainya. Untuk kelas 12, meskipun UN dihapuskan, siswa masih merasa tertekan karena harus fokus pada Ujian Tulis Berbasis Komputer (UTBK) untuk masuk perguruan tinggi secara individu tanpa ada arahan dari sekolah (Gusella, 2020). Penundaan penilaian-penilaian mengenai keahlian juga membuat siswa tidak bisa mendapatkan tambahan keterampilan secara praktik di lapangan. Pembatalan acara dan penilaian ini menimbulkan dampak secara psikologis pada siswa SMA, seperti kesepian dan kecemasan.

Penelitian Sagita \& Hermawan (2020) menunjukkan bahwa tingkat kesepian yang dialami subjeknya selama pandemi yaitu cukup tinggi sebesar 43\%, tinggi 10\%, dan sangat tinggi 1,7\%. Kesepian ini dapat memunculkan gejala-gejala stres karena tidak adanya dukungan sosial pada individu sehingga merasa tak ada seorangpun yang bisa memahaminya (Suryaningsih, dkk., 2016). Selain itu kecemasan juga berpengaruh pada stres akademik. Kecemasan siswa SMA di masa Covid-19 muncul dikarenakan halhal yang berkaitan dengan pembelajaran, seperti kesulitan memahami materi, kesulitan mengerjakan tugas-tugas, ketersediaan dan kondisi jaringan internet, kendala teknis, dan kekhawatiran akan pemilihan jurusan di jenjang berikutnya (Oktawirawan, 2020). Kecemasan-kecemasan tersebut dapat mendorong siswa mengalami stres akademik.

Dampak lain dari pembelajaran jarak jauh adalah adanya angka putus sekolah dan pernikahan dini. Meningkatnya masalah tersebut selama pandemi disebabkan keluarga anak merasa bingung, stres, bahkan kesal ketika sekolah ditutup sehingga keluarga menambah peran menjadi guru di rumah dan menganggap sekolah tidak bertanggung jawab pada anaknya (Andina, 2021). Kasus pernikahan dini tersebut banyak terjadi pada siswa-siswi SMA yang masih berusia 16-19 tahun (Utomo, 2021).

Selama pembelajaran jarak jauh, siswa SMA dituntut untuk mempelajari dan memahami tugas sendiri tanpa ada penjelasan detail dari guru serta kurang adanya interaksi antara guru dengan siswa dan siswa dengan siswa. Siswa SMA yang belum terbiasa akan sistem pembelajaran seperti ini akan mengalami 
ketertinggalan di bidang akademik dan menganggap tugas-tugas sekolah sebagai tekanan. Ditambah dengan adanya Pembelajaran Jarak Jauh (PJJ) mengharuskan mereka berdiam diri di dalam rumah dengan tugas-tugas yang menumpuk, kekhawatiran akan jaringan dan kuota internet yang tidak mendukung, serta semakin berkurangnya interaksi tatap muka dengan teman-teman sebayanya, membuat tidak sedikit dari mereka mengalami stres di bidang akademik.

Sun, dkk. (2011) mendefinisikan stres akademik sebagai suatu stres yang bersumber tidak hanya dari ekspektasi akademis yang tinggi, melainkan dari faktor lain yaitu beban tugas sekolah dan pekerjaan rumah yang berat, sikap negatif terhadap pembelajaran, seperti ketidakpuasan dengan nilai dan kehilangan minat; serta kesulitan dalam belajar juga dapat menjadi sumber tekanan dan stres yang penting di kalangan siswa. Menurut Helman \& Kariv (2005, dalam Amini, 2020), stres akademik terbentuk apabila siswa memperoleh tekanan dalam bidang akademik salah satunya adalah serbuan banyak tugas yang wajib ia selesaikan.

Kenyataannya bisa dilihat dari hasil survei Komisi Perlindungan Anak Indonesia (KPAI) terkait PJJ. Responden dari survei ini didominasi oleh siswa SMA (64,5\%). Hasilnya menunjukkan bahwa stres akibat belajar di rumah dapat ditunjukkan dari jawaban-jawaban respondennya, seperti 79,9\% responden mengatakan bahwa proses pembelajaran jarak jauh tidak ada interaksi di dalamnya sehingga siswa tidak bisa menanyakan apa yang belum dimengerti dari materi pelajarannya dan guru hanya memberikan tugas berat saja, 73,2\% anak merasa berat mengerjakan tugas-tugas yang diberikan karena guru memberikan waktu yang sempit, dan sebanyak 77,8\% siswa mengaku kesulitan tertinggi dari pembelajaran dari rumah ialah tugas yang menumpuk (KPAI, 2020).

Meskipun banyak siswa mengalami stres akademik yang berat, namun ada beberapa yang mampu menangani tekanan akademiknya sehingga hanya mengalami stres akademik ringan atau tidak mengalaminya sama sekali. Faktor yang mempengaruhi stres yang dialami remaja dapat berasal dari eksternal dan internal. Faktor eksternal berarti faktor-faktor yang berasal dari luar individu, seperti yang bisa dilihat dari jawaban-jawaban responden survei KPAI sebelumnya yakni tugas yang menumpuk, kurangnya interaksi anatara guru dengan siswa, hingga kendala dari jaringan internet ataupun sarana dan prasarana dalam pembelajaran daring.

Kemudian pada faktor internal, bisa berasal dari kepribadian, dalam penelitian Rahmadini \& Indrawati (2019) menunjukkan kepribadian memiliki hubungan yang signifikan $(r=0,280)$ dengan stres akademik; self-efficacy, dalam penelitian Sagita, dkk. (2017) menunjukkan jika self-efficacy memiliki hubungan signifikan dengan stres akademik $(\mathrm{r}=-0,300)$; optimisme, jika dilihat dari penelitian Assyahidah \& Musabiq (2015) dapat ditunjukkan bahwa optimisme berkorelasi negatif secara signifikan $(\mathrm{r}=-0,158)$, dan psychological well-being yang memiliki nilai hubungan yang lebih besar $(\mathrm{r}=$ 0,649) (Aulia \& Panjaitan, 2019).

Oleh karena itu, psychological well-being dipilih untuk menjadi faktor penyebab stres akademik karena memiliki hubungan yang lebih kuat daripada beberapa faktor lain. Kejahteraan psikologis sendiri penting untuk didapatkan siswa di masa Covid-19. Selain sehat secara fisik, sejahtera secara psikologis juga sangat penting untuk melindungi diri dari paparan virus corona. Kondisi psikologis yang sejahtera menjadi dasar kuatnya imunitas tubuh di masa seperti ini (Priyasmoro, 2020).

Kesejahteraan psikologis merupakan kemampuan individu untuk menerima diri apa adanya, membentuk hubungan yang erat dengan orang lain, memiliki kemandirian, mengontrol lingkungan 
eksternalnya, memiliki tujuan dalam hidupnya, serta mampu merealisasikan potensi dalam dirinya secara berkelanjutan (Ryff, Happiness is everything, or is it? exploration on the meaning of psychological well-being, 1989).

Beberapa penelitian mengungkapkan jika tinggi rendahnya stres dipengaruhi oleh kesejahteraan psikologis. Penelitian yang dilakukan Aulia \& Panjaitan (2019) menemukan bahwa ada hubungan yang kuat antara kesejahteraan psikologis dengan stres akademik, penelitian Sarina (2012) juga menemukan bahwa terdapat hubungan negatif antara psychological well-being dengan stres akademik, sehingga semakin tinggi psychological well-being yang dimiliki individu maka semakin rendah tingkat stres akademik yang dialaminya. Selain itu, Sugiura, dkk. (2005) menyimpulkan jika stres akademik yang dialami oleh subjeknya dipengaruhi oleh psychological well-being.

Berdasarkan argumentasi-argumentasi yang telah dijelaskan sebelumnya, penulis tertarik untuk meneliti lebih lanjut mengenai apakah psychological well-being memiliki pengaruh terhadap stres akademik siswa SMA di masa Covid-19. Berdasarkan tinjauan literatur yang dilakukan oleh penulis, stres akademik berkolerasi negatif dengan psychological well-being, seperti pada penelitian Akhtar (2018), Aloia \& McTigue (2019), dan Munir, dkk. (2015). Namun Duncan-Williams (2015) dan Cole, dkk. (2014) menunjukkan hasil penelitiannya berkolerasi positif antara stres akademik dan psychological well-being. Di beberapa penelitian sebelumnya sudah cukup menjelaskan bagaimana hubungan kedua variabel tersebut. Maka dari itu penulis dalam penelitian ini memilih untuk mengetahui seberapa besar pengaruh psychological well-being terhadap stres akademik siswa SMA di masa Covid-19.

\section{E T O D E}

\section{Desain Penelitian}

Penelitian ini menggunakan metode kuantitatif, yakni menekankan pada data-data kuantitatif yang dikumpulkan melalui prosedur pengukuran dan diolah dengan metode analisis statistika (Azwar, 2017). Selain itu penelitian ini juga menggunakan tipe penelitian asosiatif kausal karena penelitian ini bertujuan untuk mengetahui apakah psychological well-being mempengaruhi tingkat stres akademik siswa SMA di masa Covid-19. Menurut Sugiyono (2010), penelitian asosiatif kausal merupakan penelitian yang bertujuan untuk mengetahui hubungan antara dua variabel atau lebih. Berdasarkan tujuannya, penelitian ini termasuk tipe explanatory research yang bertujuan untuk menjelaskan prediksi satu variabel terhadap variabel lain serta menguji hipotesis yang telah dirumuskan (Neuman, 2014).

\section{Partisipan}

Partisipan yang berpartisipasi dalam penelitian ini adalah siswa SMA yang sedang mengikuti pembelajaran jarak jauh. Partisipan telah mengisi informed consent sebelum mulai mengisi kuisioner yang disebar. Teknik sampling menggunakan non probability sampling dengan metode purposive sampling. Dalam penelitian ini, penulis menggunakan pedoman Roscoe (1975, dalam Azwar, 2017) untuk menentukan jumlah sampel. Salah satu pedoman yang diusulkan Roscoe yaitu jika sampel dengan ukuran $n>30$ dan $n<500$ sudah cukup untuk riset pada umumnya. 


\section{Pengukuran}

Brief Scale of Psychological Well-Being for Adolescence (BSPWB-A) adalah skala yang dikembangkan oleh Viejo, dkk. (2018) dengan dimensi psychological well-being terdiri dari 4 dimensi yaitu: self-acceptance, positive relation with others, autonomy, dan personal growth. Skala ini merupakan skala adaptasi dari Scale of Psychological Well-Being (SPWB) milik Ryff (1989) yang dirancang juga divalidasi dalam populasi remaja.

Alat ukur ini terdiri dari 20 item dengan menggunakan skala Likert yaitu skala 1 (sangat tidak setuju), 2 (tidak setuju), 3 (agak tidak setuju), 4 (agak setuju), 5 (setuju), dan 6 (sangat setuju). Untuk penilaiannya adalah dengan menjumlahkan jawaban-jawaban di tiap partisipan dengan sebelumnya membalik nilai pada item-item unfavorable. Semakin tinggi total skor menunjukkan semakin tinggi tingkat psychological well-being individu tersebut.

Educational Stress Scale for Adolescents (ESSA) dikembangkan oleh Sun, dkk. (2011). Alat ukur ini terdiri dari 5 dimensi, antara lain: pressure from study, workload, worry about grades, self-expectation, despondency. Skala ini terdiri dari 16 aitem, dengan skala Likert pilihan 1 (sangat tidak setuju), 2 (tidak setuju), 3 (setuju), 4 (sangat setuju). Untuk penilaiannya adalah dengan menjumlahkan jawabanjawaban di tiap partisipan. Semakin tinggi total skor menunjukkan semakin tinggi tingkat psychological well-being individu tersebut.

Sebelum melakukan uji analisis data dilakukan uji asumsi terlebih dahulu. Uji normalitas menunjukkan bahwa residual data berdistribusi normal, uji linieritas data menunjukkan bahwa kedua variabel berhubungan linier secara signifikan $(0,00<0,05)$, dan uji homokedastisitas menunjukkan bahwa tidak terjadi heterokedastisitas. Maka dari itu, data dalam penelitian ini telah memenuhi persyaratan untuk melakukan uji regresi linier sederhana.

\section{Analisis Data}

Dalam penelitian ini menggunakan teknik analisis regresi linier sederhana untuk mengukur pengaruh variabel psychological well-being terhadap variabel stres akademik. Perhitungan statistik ini menggunakan program SPSS 22.0 for Microsoft Windows.

\section{HAS I L P EN EL I T IAN}

Jumlah partisipan dalam penelitian ini sebanyak 147 orang. Nilai minimum untuk variabel psychological well-being dan stres akademik berturut-turut ialah 20 dan 16, sedangkan untuk nilai maksimum ialah 120 dan 64. Nilai mean dan standar deviasi dalam penelitian ini menggunakan perhitungan statistik hipotetik. Nilai mean hipotetik dan standar deviasi hipotetik psychological well-being (Mhipotetik=70; SDhipotetik=16,7) dan stres akademik (Mhipotetik=40; SDhipotetik=8). Kemudian untuk range variabel psychological well-being sebesar 100 dan variabel stres akademik sebesar 48.

Kategorisasi dalam penelitian ini membagi partisipan menjadi 3 kategori, yaitu rendah, sedang, dan tinggi. Penormaan yang digunakan adalah statistik hipotetik, menggunakan alat ukur sebagai acuan. Pengategorian menggunakan statistik hipotetik dapat menghasilkan proporsi yang tidak selalu mengikuti kurva normal (Widhiarso, 2010). Untuk pengelompokkan data berdasarkan norma hipotetik, penulis menggunakan penormaan yang mengacu pada kategorisasi norma yang dibentuk oleh (Azwar,

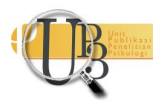


1993). Hasil perhitungan manual didapatkan partisipan yang memiliki psychological well-being sedang sebanyak 135 orang $(91,8 \%)$ dan tinggi 12 orang $(8,2 \%)$. Sementara partisipan yang mengalami stres akademik dalam kategori rendah sebanyak 5 orang (3,4\%), kategori sedang sebanyak 101 orang $(68,7 \%)$, dan kategori tinggi sebanyak 41 (27,9\%).

Setelah dilakukan analisis regresi linier menunjukkan data $(\mathrm{t}(23,606)>\mathrm{t}$ tabel $(1,976) ; p<0,05)$ menunjukkan bahwa variabel psychological well-being memiliki pengaruh yang signifikan terhadap stres akademik. Selanjutnya didapatkan persamaan $Y=79,637-0,453$ dari model ini. Dari persamaan tersebut dapat diketahui jika psychological well-being berpengaruh secara negatif terhadap stres akademik. Sementara nilai psychological well-being $(\mathrm{B}=-0,453)$, tanda minus menunjukkan bahwa apabila kenaikan satu nilai pada psychological well-being maka akan menurunkan stres akademik sebesar 0,453 .

Kemudian hasil analisis juga menunjukkan kekuatan hubungan kedua variabel dan besar pengaruh variabel psychological well-being terhadap stres akademik $\left(\mathrm{R}=0,648 ; \mathrm{R}^{2}=0,420\right)$. Varians prediktor dapat menjelaskan 42 persen dari varians variabel dependen, sedangkan 58\% dari stres akademik berasal dari variabel lain yang tidak diteliti. Menurut Cohen (1988 dalam Pallant, 2010), nilai R dalam penelitian ini termasuk dalam kategori kekuatan korelasi yang tinggi karena mendekati angka 1.

\section{I S K U S I}

Tujuan dari penelitian ini adalah untuk mencari pengaruh psychological well-being terhadap stres akademik pada siswa SMA di masa Covid-19. Untuk mencapai tujuan tersebut, penulis melakukan uji statistik menggunakan uji regresi linear sederhana guna menjawab rumusan masalah serta menguji hipotesis penelitian.

Pada penelitian ini diperoleh hasil yang menunjukkan bahwa dari 147 subjek, terdapat 101 subjek $(68,7 \%)$ dengan stres akademik sedang dan 41 subjek $(27,9 \%)$ mengalami stres akademik yang tinggi. Hasil mengenai stres akademik dalam penelitian ini menunjukkan bahwa subjek mengalami stres akademik selama masa Covid-19, namun dominan ke kategori sedang. Ini selaras dengan penelitian yang dilakukan oleh Rahmayani, dkk. (2021), yaitu seluruh subjeknya mengalami stres akademik dan juga sama-sama dominan di kategori sedang. Hal tersebut menunjukkan bahwa subjek dalam penelitian ini tidak terlalu sering mengalami stresor akademis dan bereaksi terhadap stres. Hasil ini mungkin didapat karena adanya perbedaan latar belakang pendidikan yang ditempuh, sehingga tuntutan akademis yang dialami juga berbeda-beda.

Menurut Ningsih, dkk. (2020) kondisi selama pandemi ini tentunya membuat siswa merasa tidak nyaman dan tidak betah belajar sehingga memicu academic stressor. Stres akademik muncul pada individu karena adanya academic stressor yang terjadi pada proses kegiatan belajar mengajar seperti banyaknya tugas yang harus diselesaikan, lama belajar, dan mendapat nilai ulangan yang jelek (Nurmaliah, 2014).

Freire, dkk. (2016) mengemukakan bahwa respon stres tidak bergantung sepenuhnya hanya pada adanya stresor di lingkungan, tapi juga pada bagaimana stressor ini dipersepsikan oleh seseorang (penilaian kognitif) dan apa saja sumber daya serta strategi yang digunakan untuk melakukan kopingnya (proses koping). Melalui penilaian kognitif, individu akan menilai apakah stresor tersebut positif atau akan menimbulkan efek negatif bagi dirinya. Apabila tidak membawa implikasi apapun pada 
kesejahteraan dirinya (menganggap stresor sebagai hal yang positif), maka stresor tersebut tidak akan dijadikan sebagai pemicu munculnya stres. Namun apabila stresor tersebut mengancam kesejahteraan kita, maka seseorang akan mengumpulkan sumber daya internal atau eksternal untuk melakukan koping.

Oleh karena itu, mereka yang memiliki skor lebih tinggi di kesejahteraan psikologis cenderung mengadopsi strategi koping yang adaptif, seperti komitmen, penilaian ulang positif, atau mencari dukungan instrumental dan emosional (Aulia \& Panjaitan, 2019). Namun mereka yang memiliki skor lebih rendah di psychological well-being cenderung menggunakan strategi koping yang lebih tidak fungsional, seperti menyalahkan diri sendiri, mengabaikan masalahnya, atau berlindung dalam pikiranpikiran fantastis (Aulia \& Panjaitan, 2019).

Sugiura, dkk. (2005) mengindikasikan bahwa murid-murid yang memiliki psychological well-being tinggi memiliki pengalaman yang sedikit mengalami stres akademik. Dari beberapa variabel penelitian (social background, health behaviour, dan psychological well-being) yang digunakan dalam penelitian tersebut, psychological well-being merupakan pilihan pertama dalam penerimaan dan jenis kelamin dengan memberikan sumbangan sebanyak 31\%.

Freire, dkk. (2016) menemukan jika psychological well-being (lebih khususnya pada dimensi selfacceptance, enviromental mastery, purpose in life, dan personal growth) merepresentasikan sumber daya pribadi yang nilainya tidak perlu dipertanyakan lagi untuk mendukung pengambilan koping adaptif dalam tuntutan akademik. Penelitian ini berkontribusi untuk memperluas spektrum intervensi yang bertujuan untuk mengurangi stres siswa, menangani masalah ini dari perspektif proaktif yang terfokus pada pengembangan kekuatan dan kemampuan individu dalam menilai suatu tuntutan kehidupan secara positif.

Kesejahteraan psikologis dapat dikonseptualisasikan sebagai kumpulan keadaan afektif positif yang mengacu pada konsep kebahagiaan, kesejahteraan seseorang, minat, dan kualitas hidup (Malik, dkk., 2020). Namun dalam penelitian Duncan-William (2015), psychological well-being dikonseptualisasikan sebagai variabel yang memiliki dua komponen, yaitu komponen positif dan negatif. Berdasarkan hasil penelitiannya, stres akademik berasosiasi negatif pada komponen positif (disebut dengan pengaruh positif). Sebaliknya, stres akademik berasosiasi positif dengan komponen negatif (psychological distress, seperti kecemasan, depresi, dan somatisasi). Berarti individu yang mengalami kesulitan di bidang akademik berhubungan dengan gejala-gejala kecemasan, depresi, dan somatisasi, sedangkan individu yang mampu menangani kesulitan di bidang akademik akan merasakan pengaruh positif, seperti kebahagiaan, antusiasme, dan kepuasan.

Siswa SMA dapat digolongkan di masa remaja. Remaja yang masih menempuh pendidikan formal, lebih rentan mengalami disfungsi psikososial yang bersumber dari tuntutan akademis. Secara teoritis siswa sendiri memiliki kecenderungan stres belajar sesuai dengan kondisi internal siswa yang dilihat dari pikiran-pikiran negatif, keyakinan dalam diri, dan kepribadian yang dimiliki siswa (Olejnik \& Holschuh, 2007). Lebih spesifik pada masa Covid-19 seperti ini, adanya perubahan sistem pembelajaran yang drastis membuat tidak sedikit dari remaja mengalami disfungsional secara psikososial. Selain adanya perasaan kesepian (Sagita \& Hermawan, 2020) dan perasaan tidak berdaya (Singh, dkk., 2020) yang dialami remaja, pembelajaran di sekolah maupun perguruan tinggi beralih menjadi daring di masa Covid-19 menumbuhkan masalah-masalah psikologis lainnya, seperti stres (Rahmayani, dkk., 2021), kecemasan (Fitria \& Ifdil, 2020), maupun trauma (Meutia, 2020) 
Oleh karena itu seperti yang telah ditunjukkan oleh beberapa penelitian di atas, siswa rentan mengalami stres utamanya di bidang akademik. Maka diperlukan untuk lebih mempersiapkan strategi koping adaptif guna mengurangi gejala-gejala stres akademik tersebut. Strategi koping yang adaptif dapat dibentuk dengan meningkatkan kesejahteraan psikologis yang ada di dalam setiap individu (Freire, dkk., 2016).

Dengan meningkatkan penerimaan pada diri, memperbaiki hubungan dengan orang lain, mampu melakukan aktifitas secara mandiri, mampu mengatur dan menguasai lingkungannya, menentukan tujuan hidup ke depannya, dan mampu mengembangkan potensi-potensi yang ada di dalam diri secara berkelanjutan dapat dijadikan sumber daya pribadi untuk membentuk koping adaptif dalam menghadapi berbagai stresor. Hal ini selaras dengan pernyataan Bowman (2010) yang mana kesejahteraan psikologis itu sangat dibutuhkan pada masa transisi seperti ini.

\section{S I M P U L A N}

Penelitian ini bertujuan untuk melihat adanya pengaruh psychological well-being terhadap stres akademik siswa SMA di masa Covid-19. Tingkat psychological well-being yang dimiliki individu dalam penelitian ini dapat memprediksikan dan menggambarkan stres akademik sebesar $42 \%$, sedangkan $56 \%$ sumbangan efektif dari variabel stres akademik dipengaruhi oleh faktor-faktor lain yang tidak diteliti dalam penelitian.

Penelitian ini merekomendasikan supaya peneliti lain yang hendak meneliti variabel serupa, menambah jumlah partisipan dan memiliki penyebaran yang merata agar bisa menggambarkan siswa SMA di Indonesia. Selain itu, peserta didik sendiri hendaknya tetap memperhatikan kesejahteraan psikologisnya supaya terhindar dari stres akademik. Hal ini dapat dilakukan dengan cara mindfullness, melatih penerimaan diri dan kemandirian, mencari dukungan sosial, dan meningkatkan hubungan positif dengan orang lain.

\section{UCAPAN TERIMAKASIH}

Penulis mengucapkan terima kasih kepada seluruh pihak yang membantu dan terlibat dalam penelitian ini, khususnya pada Ibu Veronika Suprapti selaku dosen pembimbing dan Dosen Psikologi Universitas Airlangga, serta keluarga dan teman-teman yang telah memberi dukungan untuk kelancaran penelitian ini.

\section{DEKLARASI POTENSI TERJADINYA KONFLIK KEPENTINGAN}

Zakiya Ainun Oktaviani dan Veronika Suprapti tidak bekerja, menjadi konsultan, memiliki saham, atau menerima dana dari perusahaan atau organisasi manapun yang mungkin akan mengambil untung dari diterbitkannya naskah ini. 


\section{PUSTAKA ACUAN}

Akhtar, M. (2012). Acculturative stress and its association with academic stress and psychological wellbeing of international students. Disertasi, Universitas Gottingen.

Aloia, L. S., \& McTigue, M. (2019). Buffering against sources of academic stress: the influence of supportive informational and emotional communication on psychological well-being. Communication Research Reports, 36(2), 126-135.

Amini, N. A. (2020). Dampak pandemi covid-19 terhadap sektor pendidikan terutama bagi pelajar. Retrieved from Psyarxiv: http://psyarxiv.com/x3m96/

Andina, E. (2021, Februari). Meningkatnya angka perkawinan anak saat pandemi covid-19. Bidang Kesejahteraan Sosial Info Singkat, 13(4), 13-18.

Assyahidah, L. N., \& Musabiq, S. (2015). Hubungan antara optimisme dan stres pada mahasiswa penerima bidikmisi di Universitas Indonesia. Mediapsi.

Aulia, S., \& Panjaitan, U. (2019). Kesejahteraan psikologis dan tingkat stres pada mahasiswa tingkat akhir. Jurnal Keperawatan Jiwa, 7(2), 127-134.

Azwar, S. (1993). "Kelompok subjek ini memiliki harga diri yang rendah"; kok tahu...? Buletin Psikologi, $2,13-17$.

Azwar, S. (2017). Meode Penelitian Psikologi Edisi II. Yogyakarta: Pustaka Belajar.

Bowman, N. A. (2010). The development of psychological well-being among first college students. Journal of College Students Development, 51, 180.

CDC. (2020, Februari 15). Global Covid-19. Retrieved September 10, 2020, from Center for Disease Control (CDC) and Prevention.: http://www.cdc.gov/coronavirus/2019-ncov/global-covid19/index.html

Cole, N. N., Nonterah, C. W., Utsey, S., Hook, J., Hubbard, R., Opare-Henaku, A., \& Fischer, N. L. (2015). Predictor and moderator effects of ego resilience and mindfullness on the reliationship between academic stress and psychological well-being in a sample of Ghanaian College students. Journal of Black Psychology, 41(4), 340-357.

Duncan-Williams, B. (2015). Academic stress, academic performance and the psychological well-being of senior high school remedial students in the greater ACCRA Region of Ghana. Thesis, Universitas Ghana.

Fitria, L., \& Ifdil, I. (2020). Kecemasan remaja pada masa pandemi covid-19. Jurnal Educatio, 6(1), 1-4.

Freire, C., Ferradas, M., Valle, A., Nunez, J., \& Vallejo, G. (2016). Profiles of psychological well-being and coping strategies among university students. Frontiers in Psychology, 7(1554).

Gusella, M. (2020). Gambaran stres akademis siswa selama pandemi covid-19. Jurnal Penelitian dan Pengukuran Psikologi . 
KPAI. (2020, Mei 8). Survei pelaksanaan pembelajaran jarak jauh (PJJ) dan sistem penilaian jarak jauh berbasis pengaduan KPAI. Retrieved Februari 2021, from Bank Data Perlindungan Anak: https://bankdata.kpai.go.id/infografis/survei-pelaksanaan-pembelajaran-jarak-jauh-pjj-dansistem-penilaian-jarak-jauh-berbasis-pengaduan-kpai

Malik, M., Saidin, N., Wab, R., \& Nordin, N. (2020). Investigating the relationship stres and psychological well-being among foundation students of UiTM. International Journal of Academic Research, 10(14), 93-101.

Meutia, A. (2020). Dampak pandemi covid-19 pada psikis dan ingatan anak. ESJ (Elementary School Journal), 10(1), 60-66.

Munir, T., Shafiq, S., Ahmad, Z., \& Khan, S. (2015). Impact of loneliness and academic stress on psychological well-being among college students. Academic Research International, 6(2), 343-355.

Neuman, M. L. (2014). Social research methods: qualitative and quantitatives approaches seventh edition. USA: Pearson.

Ningsih, S., Yandri, H., Sasferi, N., \& Juliawati, D. (2020). An analysis of junior high school students' learning stress levels during the covid-19 outbreak: review of gender differences. Psychocentrum Review, 2(2), 69-76.

Nurmaliah, F. (2014). Menurunkan stres akademik siswa dengan menggunakan teknik self-instruction. Jurnal Pendidikan Humaniora, 2(3), 273-282.

Oktawirawan, D. H. (2020). Faktor pemicu kecemasan siswa dalam melakukan pembelajaran daring di masa covid-19. Jurnal Ilmiah Universitas Batanghari Jambi, 20(2), 541-544.

Olejnik, S., \& Holschuh, J. P. (2007). College rules! 2nd Edition How to study survive, and succeed in college. New York: Ten Speed Press.

Pallant, J. (2010). SPSS Survival Manual: A Step by Step Guide to Data Analysis Using SPSS 4th Edition. Berkshire: Open University Press.

Priyasmoro, M. R. (2020, Mei 10). Ahli ingatkan pentingnya kesejahteraan psikologi untuk tangani corona. Retrieved Februari 2021, from Liputan6: https://www.liputan6.com/news/read/4250187/ahli-ingatkan-pentingnya-kesejahteraanpsikologi-untuk-tangani-corona

Rahmadini, A., \& Indrawati, E. (2019). Hubungan antara trait conscientiousness dan konsep diri dengan stres akademik siswa IPA SMA X Tambun. Jurnal IKRA-ITH Humaniora, 3(3), 178-187.

Rahmayani, D., Umari, T., \& Yakub, E. (2021). Academic stress of senior high school students 1 Sand Turkish during blood learning in the covid-19 pandemic period. JOM FKIP, 8(1), 1-13.

Ryff, C. (1989). Happiness is everything, or is it? exploration on the meaning of psychological well-being. Journal American Psychological Association, 57(6), 1069-1081.

Sagita, D. D., Daharnis, \& Syahniar. (2017). Hubungan self-efficacy, motivasi berprestasi, prokrastinasi akademik, dan stres akademik mahasiswa. Jurnal Bikotetik, 1(2), 43-52. 
Sagita, D., \& Hermawan, D. (2020). Kesepian remaja pada masa pandemi covid-19. Enlighten: Jurnal Bimbingan Konseling Islam, 3(2), 122-130.

Sarina, N. Y. (2012). Hubungan antara stres akademis dan psychological well-being pada mahasiswa tahun pertama Universitas Indonesia. Skripsi, Universitas Indonesia.

Singh, S., Roy, D., Sinha, K., Parveen, S., Sharma, G., \& Joshi, G. (2020). Impact of COVID-19 and lockdown on mental health of children and adolescents: A narrative review with recommendations. Psychiatry Res, 293(113429).

Sugiura, G., Shinada, K., \& Kawaguchi, Y. (2005). Psychological well-being and perceptions of stress amongst japanese dental students. European Journal of Dental Education, 9, 17-25.

Sugiyono. (2010). Metode Penelitian Pendidikan Pendekatan Kuantitatif, Kualitatif, dan R\&D. Bandung: Alfabeta.

Sun, J., Dunne, M. P., Hou, X., \& dan Xu, A. (2011). Educational stress scale for adolescents: development, validity, and reliability with chinese students. Journal of Psychoeducational Assesment, 29(6), 534546.

Suryaningsih, F., Karini, S. M., \& Karyanta, A. N. (2016, Maret). Hubungan antara self-disclosure dengan stres pada remaja siswa SMP Negeri 8 Surakarta. Jurnal Ilmiah Psikologi Candrajiwa, 4(4).

Utomo, P. (2021, April 5). Angka pernikahan dini di Jateng meningkat tajam selama pandemi. Retrieved Juni 9, 2021, from rri.co.id: https://rri.co.id/semarang/1050-info-publik/1016298/angkapernikahan-dini-di-jateng-meningkat-tajam-selama-pandemi

Viejo, C., Gomez-Lopez, M., \& Ortega-Ruiz, R. (2018). Adolescent's psychological well-being. International Journal of Enviromental Research and Public Health, 15(2325), 1-22.

Widhiarso, W. (2010). Membuat kategori skor hasil pengukuran dari skala. Retrieved Juni 6, 2021, from Universitas Gadjah Mada: http://widhiarso.staff.ugm.ac.id/wp/wp-content/uploads/WidhiarsoPengategorian-Data-dengan-Menggunakan-Statistik-Hipotetik-dan-Statistik-Empirik.pdf 